ISSN 1027-5495. Functional Materials, 24, No.4 (2017), p. 706-714

doi:https://doi.org/10.15407/fm24.04.706

(C) 2017 - STC “Institute for Single Crystals"

\title{
New effective sorbents for purification of aqueous media from technogenic contaminants
}

\author{
S.V.Khimchenko', T.A.Blank ${ }^{1}$, K.N.Belikov ${ }^{1,2}$, K.Yu.Bryleva ${ }^{1}$, \\ I. B.-Kh.Shcherbakov ${ }^{1}$, V.A.Chebanov ${ }^{1,2}$, E.A.Muravyova ${ }^{1}$, \\ V.E.Saraev ${ }^{1}$, I.M.Zviagin', S.A.Komykhov ${ }^{1,2}$, \\ K.S.Ostras ${ }^{1}$, V.N.Chernenko ${ }^{1,2}$ \\ ${ }^{1}$ SSI "Institute for Single Crystals", National Academy of Sciences \\ of Ukraine, 60 Nauky ave., Kharkiv 61178, Ukraine \\ ${ }^{2}$ V.N.Karazin Kharkiv National University, 4 Svobody sq., \\ Kharkiv 61077, Ukraine
}

\section{Received July 7, 2017}

Created are the sorbents based on silica gel non-covalently modified with partially hydrogenated heterocyclic compounds (PHHC), containing nitrogen as donor atoms for purification of aqueous media from technogenic contaminants. The investigations show that the modified silica gel is characterized by a sorption capacity relatively higher than that of unmodified one. The sorption degree of metal ions is studied depending on their concentrations, total mineralization and $\mathrm{pH}$ value of the solutions. Conditions for selective sorption of microquantities of Eu ${ }^{3+}$ which has been used as chemically identical to ${ }^{241} \mathrm{Am}$ are described. Moreover it was shown that PHHCmodified silica gel was potential to use as the sorbent to concentrate the $\mathrm{Eu}^{3+}$ and $\mathrm{Sr}^{2+}$ metal ions with initial concentrations near $1 \mathrm{mg} \cdot \mathrm{L}^{-1}$ for the quantitative analysis. Also the possible mechanism of metal ion sorption on the developed sorbents was proposed.

Keywords: sorbent, modified silica gel, sorption degree, partially hydrogenated heterocyclic compounds, metal ions.

Разработаны сорбенты на основе силикагеля, нековалентно модифицированного частично гидрированными гетероциклическими соединениями (РННС), содержащими азот в качестве донорных атомов, для очистки водных сред от техногенных загрязнений. Показано, что модифицированный силикагель по сравнению с немодифицированным характеризуется более высокой сорбционной емкостью. Получены экспериментальные зависимости степени сорбции ионов металлов на разработанных сорбентах от величины рН и общей минерализации растворов. Установлены концентрационные зависимости степени сорбции металло-ионов из водных растворов. Описаны условия селективной сорбции микросодержаний Еu ${ }^{3+}$, который использовался в качестве химического аналога ${ }^{241} \mathrm{Am}$. Показано, что силикагель, модифицированный РННС, также пригоден для концентрировании металло-ионов $\mathrm{Eu}^{3+}$ и $\mathrm{Sr}^{2+}$ с начальными концентрациями около 1 мг· ${ }^{-1}$ при проведении количественного анализа. Описан возможный механизм сорбции металло-ионов на разработанных сорбентах. 
Нові ефективні сорбенти для очищення водних середовищ від техногенних забруднень. С.В.Хилченко, Т.А.Бланк, К.М.Беліков, К.Ю.Брильова, І.Б.-Х.Щербаков, В.А.Чебанов, О.О. Муравйова, В.С.Сараєв, Є.М.Звягін, С.О.Колихов, К.С.Острась, В.М.Черненко

Розроблені сорбенти на основі силікагелю, який був нековалентно модифікований частково гідрованими гетероциклічними сполуками (РНHC), що містять азот в якості донорних атомів для очищення водних середовищ від техногенних забруднень. Показано, що модифікований силікагель має більш високу сорбційну емність ніж немодифікований. Отримано експериментальні залежності ступеня сорбції іонів металів на розроблених сорбентах від величини $\mathrm{pH}$ та загальної мінералізації розчинів. Встановлено концентраційні залежності ступеня сорбції метало-іонів із водних розчинів. Описано умови селективної сорбції мікрокількісного вмісту $\mathrm{Eu}^{3+}$, який був використаний в якості хімічного аналога ${ }^{241} \mathrm{Am}$. Показано, що силікагель, модифікований РННС, також придатний для концентрування метало-іонів $\mathrm{Eu}^{3+} \mathrm{i} \mathrm{Sr^{2+ }}$ із початковими концентраціями близько 1 мг· ${ }^{-1}$ під час проведення кількісного аналізу. Був запропонований можливий механізм сорбції метало-іонів на розроблених сорбентах.

\section{Introduction}

Intensity of mining-metallurgical and nuclear industries has led to significant dispersion and deposition of heavy metals and technogenic radionuclides of different origin in the environment [1]. One of the impacts is visible, in form of water pollution [2]. There is an obvious need for industrial technologies for deactivation and cleaning of great amounts of surface and ground water, swamp and river ecosystems, soils [1].The conventional methods of treatment of heavy metal and radionuclide contamination include chemical precipitation, chemical oxidation or reduction, ion exchange, filtration, electrochemical treatment, membrane separation, reverse osmosis, electro dialysis, evaporation recovery etc. [3] These methods are costly, energy intensive and often associated with generation of toxic byproducts [2, 4]. Moreover these processes may occur to be ineffective or extremely expensive, especially when the metals in solution are in the concentration below $1 \mathrm{mg} \mathrm{L}^{-1}$ [3]. Therefore environmental studies are confronted with a challenging task to develop appropriate low cost technologies for treatment of liquid wastes [3]. Adsorption has emerged out to be better alternative treatment methods [1-3].

Adsorption is basically a mass transfer process by which a substance is transferred from the liquid phase to the surface of a solid, and becomes bound by physical and/or chemical interactions. It is a partition process in which few components of the liquid phase are relocated to the surface of the solid adsorbents. In general, the main steps involved in adsorption of pollutants on solid adsorbent are: transport of the pollutant from bulk solution to external surface of the adsorbent; internal mass transfer by pore diffusion from outer surface of adsorbent to the inner surface of porous structure; adsorption of adsorbate on the active sites of the pores of adsorbent. The overall rate of adsorption is decided by either film formation or intra particle diffusion or both as the last step of adsorption are rapid as compared to the remaining two steps [2]. Selective sorption of radionuclides allows to concentrate long-lived radionuclides in a small volume of sorbent and simplify treatment technology for liquid radioactive waste. Currently adsorption seems to be the easiest, safest and most cost-effective method for treatment of waste effluents containing heavy metals. The key benefit of adsorption method for heavy metal and radionuclide contamination removal is less initial as well as operation cost, unproblematic design and less requirement of control systems [2]. Unlike conventional methods adsorption is suitable even when heavy metals and radionuclides are present at concentrations as low as $1 \mathrm{mg} \cdot \mathrm{L}^{-1}[2,3]$. Therefore adsorption methods are mainly used for deep purification and posttreatment of sewage. According to the literature data, the efficiency of adsorption treatment of waste water reaches $80-95 \%$ [5].

To be commercially viable, an adsorbent should have high selectivity to facilitate quick separations, favorable transport and kinetic characteristics, thermal and chemical stability, mechanical strength, resistance to fouling, low solubility in the liquid in contact [2]. Moreover, environmentally safeness of waste sorbents disposal is required. Silica gels are chemically inert, non-toxic materials composed of amorphous silicon dioxide. They are characterized by a highly porous texture and therefore they can be utilized for synthesis of adsorbents with 
preset structural characteristics and various chemical surfaces. In addition, the structure of silica gel is corpuscular, i.e. it consists of interconnected particles forming a three-dimensional skeleton. The particle size affects the value of the specific surface area, while the compactness of binding influences the absorption volume of the pores [6]. Adsorption properties of silica gel have been attributed to the surface hydroxyl groups of silica gel. Some hydroxyl groups are free standing and called free silanol groups. Some are hydrogen bonded to neighbouring silanol groups [7]. These groups enable the attachment of organic molecules, which can coordinate metal ions in a solution [6]. Recently, surface functionalization of ordered silica gel has attracted intensive interest in view of its use as a solid support, due to its large specific surface area and fast adsorption kinetics $[6,8]$. Physically or chemically modified silica gels with organic or inorganic compounds have been used widely as solid phases to preconcentrate metal ions from different kind of natural samples such as sea water, river water, biological samples, etc. [9]. The correct choice of a desired functional group for immobilization on the silica surface can yield materials that are highly selective for a specific contaminant [6]. Partially hydrogenated heterocyclic compounds containing functional groups capable of forming covalent chemical bonds by a donor-acceptor mechanism with radionuclides and heavy metal ions [10-12] can act as suitable organic agents for silica gel modification. A number of techniques can be used to fix an analytical reagent on a matrix. One of them is a synthetic method involving the so-called covalent grafting of a modifying reagent. Another method is impregnation of a matrix with a solution of a modifier [13]. Non-covalently modified sorbents possess a number of advantages, in particular, ease of preparation and sufficient stability. At the same time the sorption properties of such materials are defined by the complexing properties of immobilized organic reagents [14-15].

The goal of the present paper is to synthesize sorbents based on silica gel non-covalently modified with partially hydrogenated heterocyclic compounds (PHHC), containing nitrogen as donor atoms, with selective sorption toward heavy metals and radionuclides .

\section{Materials and methods}

\subsection{General}

The residual concentration of the target metal ion in the solution after sorption was determined by atomic emission spectroscopy with inductively coupled plasma (AES-ICP) on a spectrometer of TRACE SCAN Advantage (Thermo Jarrell Ash, USA). Absorption spectra were recorded using a SF-2000-02 spectrophotometer (OKB "Spectrum", St. Petersburg, Russia). The solution $\mathrm{pH}$ was measured using a $\mathrm{pH}$ OHAUS STARTER 3100 pH meter (OHAUS, USA). The solutions were stirred with a magnetic stirrer MS300 (ULAB, PRC). The residual concentration of the PHHC on the adsorbent surface after sorption was determined using a EuroEA3000 elemental analyzer (EuroVector, Italy).

All chemicals and solvents used for the synthesis, photometric measurements and adsorbent properties investigations were of analytical reagent grade, and used without further purification unless otherwise specified.

Original Silica Gel brand C-60 for column chromatography with an average pore diameter of $60 \mathrm{E}$, the mean pore volume of $0.75 \mathrm{ml} / \mathrm{g}$ and with specific surface area of $500 \mathrm{~m}^{2} / \mathrm{g}$ came from Ross (Belgium).

Merrifield Peptide Resin (particle size 100200 mesh) came from Sigma-Aldrich.

The metal ions studied were $\mathrm{Eu}^{3+}, \mathrm{Cu}^{2+}, \mathrm{Sr}^{2+}$. The former was used as chemically identical to ${ }^{241} \mathrm{Am}$. The stock standard solutions with the concentration $1 \mathrm{mg} \cdot \mathrm{L}^{-1}$ were prepared with ultrapure water obtained on a "P.NIX POWER SYSTEM" ("HUMAN CORPORATION", South

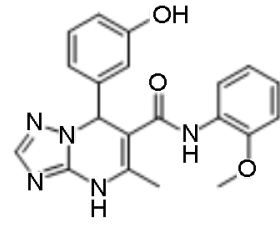

A

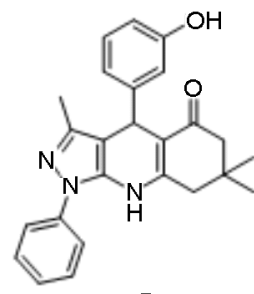

$\underline{B}$

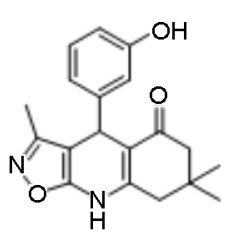

$\underline{\mathrm{C}}$

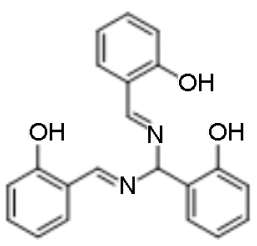

$\underline{D}$

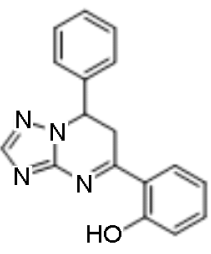

E

Scheme 1. Structures of $\underline{\mathbf{A}}-\underline{\mathbf{E}}$. 
Table 1. Spectral characteristics of the complexes with some organic compounds which are suitable for creation of hybrid sorbents

\begin{tabular}{|c|c|c|c|c|c|c|}
\hline $\begin{array}{l}\text { Organic com- } \\
\text { pounds }\end{array}$ & $\begin{array}{l}\text { Solvent of } \\
\text { the complex }\end{array}$ & $\begin{array}{c}\text { Target metal } \\
\text { ion }\end{array}$ & $\begin{array}{l}\text { Ratio of ligand: } \\
\text { metal concentra- } \\
\text { tions }\end{array}$ & $\mathrm{pH}$ & $\lambda_{\max }, \mathrm{nm}$ & $\begin{array}{l}\text { Optical den- } \\
\text { sity }\end{array}$ \\
\hline \multirow{3}{*}{$\underline{\mathbf{A}}$} & \multirow{3}{*}{$\mathrm{DMF}$} & $\mathrm{Sr}$ & $6: 1$ & 7 & 320 & 0.32 \\
\hline & & $\mathrm{Cu}$ & $6: 1$ & 7 & 388 & 0.84 \\
\hline & & Eu & $6: 1$ & 7 & 391 & 0.71 \\
\hline \multirow{2}{*}{$\underline{\mathbf{D}}$} & \multirow{2}{*}{ Ethanol } & $\mathrm{Eu}$ & $6: 1$ & 6 & 451 & 0.80 \\
\hline & & $\mathrm{Cu}$ & $6: 1$ & 6 & 400 & 1.40 \\
\hline \multirow{3}{*}{$\underline{\mathbf{B}}$} & \multirow{3}{*}{ Ethanol } & $\mathrm{Sr}$ & $6: 1$ & 7 & 378 & 0.68 \\
\hline & & $\mathrm{Cu}$ & $6: 1$ & 7 & 397 & 1.89 \\
\hline & & $\mathrm{Eu}$ & $6: 1$ & 7 & 311 & 1.30 \\
\hline \multirow{3}{*}{$\underline{\mathbf{C}}$} & \multirow{3}{*}{ Water } & $\mathrm{Sr}$ & $6: 1$ & 7 & 365 & 0.40 \\
\hline & & $\mathrm{Cu}$ & $6: 1$ & 7 & 380 & 1.15 \\
\hline & & $\mathrm{Eu}$ & $6: 1$ & 7 & 361 & 0.97 \\
\hline
\end{tabular}
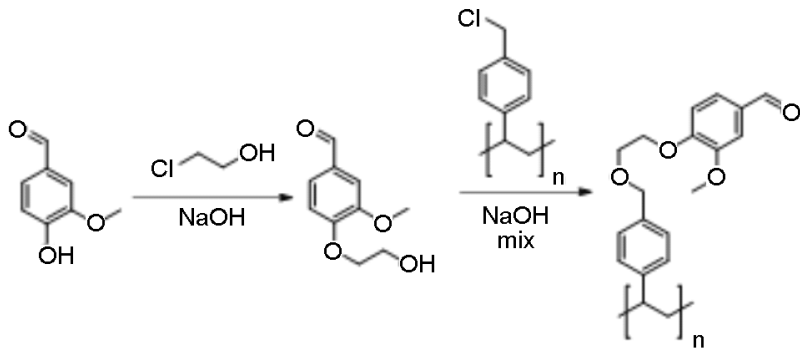

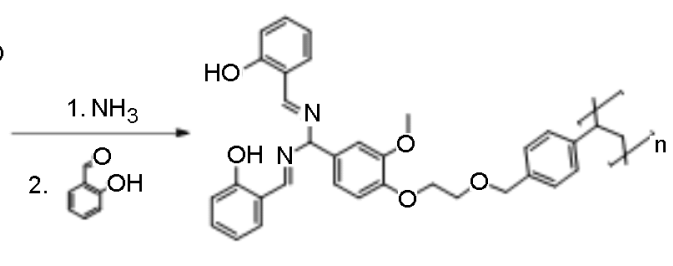

Scheme 2. Synthesis of $\underline{\mathbf{D}}$ functionalized Merrifield resin.

Korea) from standard $1000 \mathrm{mg} \cdot \mathrm{L}^{-1}$ solutions (Sigma-Aldrich).

Whatman ${ }^{\circledR}$ quantitative filter paper, ashless, Grade 589/2 white ribbon came from Sigma-Aldrich.

\subsection{Synthesis of the PHHC}

Compounds $\underline{\mathbf{A}}-\underline{\mathbf{C}}$ (Scheme 1) were prepared according to a published procedure $[16,17]$ by three-component reaction of corresponding aminoazole (3-amino-1,2,4-triazole for $\underline{\mathbf{A}}, \quad 5$-amino-3-methyl-1-phenylpyrazole for $\underline{\mathbf{B}}$, 5-amino-3-methylisoxazole for $\underline{\mathbf{C}}$ ) with 3-hydroxybenzaldehyde and methylene-active compound (o-acetoacetanisidide, dimedone) by heating in dimethylformamide with yields of $80 \%$ for $\underline{\mathbf{A}}, 68 \%$ for $\underline{\mathbf{B}}$ and $84 \%$ for $\underline{\mathbf{C}}$.

Compound $\underline{\mathbf{D}}$ (Scheme 1, $\underline{\mathbf{D}}$ ) was prepared according to a published procedure [18] by reaction of salicylaldehyde and aqueous ammonia and washing of the obtained precipitate with ethanol; the yield of the crude product was $92 \%$.

Compound $\mathbf{E}$ was prepared according to described procedure [19] from 3-amino-1,2,4-triazole and 2'-hydroxychalcone by heating of the initial substances in dimethylformamide for 20 minutes with $85 \%$ yield of the crude product.

\subsection{UV-vis measurements}

Photometric measurements were performed in $1 \mathrm{~cm}$ quartz cuvettes. The estimations of $\lambda_{\max }$ (in $\mathrm{nm}$ ) were performed with a program included in the spectrophotometer software package, running in a mode "Register the absorption spectrum". The concentration of the PHHC in the solutions for photometry was higher than the metal concentration by 2,6 or 9 times. The PHHC dissolved in a suitable solvent with the addition of $1 \mathrm{M}$ nitric acid (for $\mathrm{pH}$ equal to blank and working solutions), was used as a blank solution.

\subsection{Preparation of sorbents}

Synthesis impregnated by the PHHC sorbents based on Silica Gel

Original Silica Gel was pre-washed with $10 \%$ hydrochloric acid and dried under vacuum for 6 hours at $120^{\circ} \mathrm{C}$. PHHC $(0.2 \mathrm{~g})$ was dissolved in $50 \mathrm{ml}$ of the solvent (chloroform, ethanol or DMF) at room temperature. In a beaker with $1 \mathrm{~g}$ of silica gel $25 \mathrm{ml}$ of the PHHC solution was added. The mixture was stirred for 30 minutes on a magnetic stirrer. Then the precipitate was filtered on a paper filter. Afterwards the sorbent was dried at $80^{\circ} \mathrm{C}$ to constant weight. 
Table 2. Sorption properties of the sorbents modified by PHHC

\begin{tabular}{|c|c|c|c|c|c|c|c|}
\hline \multirow[b]{2}{*}{ 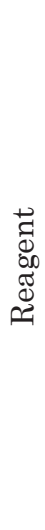 } & \multirow{2}{*}{ 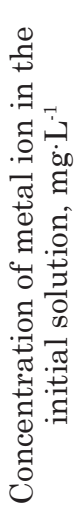 } & \multicolumn{3}{|c|}{$\begin{array}{l}\text { Found in the solution after sorption, } \\
\qquad \mathrm{mg} \cdot \mathrm{L}^{-1}\end{array}$} & \multicolumn{2}{|c|}{ Sorption degree, \% } & \multirow{2}{*}{ 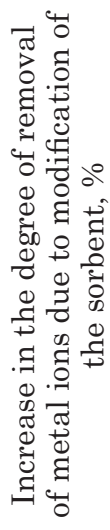 } \\
\hline & & Sorbent & $\begin{array}{c}\text { Impregnated by } \\
\text { PHHC silica gel } \\
\text { (ISG) }\end{array}$ & $\begin{array}{l}\text { Purified } \\
\text { silica gel } \\
\text { (PSG) }\end{array}$ & ISG & PSG & \\
\hline \multirow{3}{*}{$\underline{\mathbf{A}}$} & 1.02 & $\mathrm{Cu}^{2+}$ & 0.76 & 0.88 & 25.5 & 13.7 & 11.8 \\
\hline & 1.10 & $\mathrm{Eu}^{3+}$ & 0.21 & 0.295 & 80.9 & 73.2 & 7.7 \\
\hline & 1.10 & $\mathrm{Sr}^{2+}$ & 0.945 & 1.06 & 14.1 & 3.6 & 10.5 \\
\hline \multirow{3}{*}{$\underline{\mathbf{B}}$} & 0.98 & $\mathrm{Cu}^{2+}$ & 0.725 & 0.84 & 26.0 & 14.3 & 11.7 \\
\hline & 1.05 & $\mathrm{Eu}^{3+}$ & 0.12 & 0.26 & 88.6 & 75.2 & 13.4 \\
\hline & 0.99 & $\mathrm{Sr}^{2+}$ & 0.865 & 0.95 & 12.6 & 4.0 & 8.6 \\
\hline \multirow{3}{*}{$\underline{\mathrm{C}}$} & 1.00 & $\mathrm{Cu}^{2+}$ & 0.305 & 0.860 & 69.5 & 14.0 & 55.5 \\
\hline & 1.10 & $\mathrm{Eu}^{3+}$ & 0.200 & 0.295 & 81.8 & 73.2 & 8.6 \\
\hline & 1.00 & $\mathrm{Sr}^{2+}$ & 0.250 & 0.96 & 75.0 & 4.0 & 71.0 \\
\hline \multirow{3}{*}{$\underline{\mathrm{D}}$} & 1.00 & $\mathrm{Cu}^{2+}$ & 0.27 & 0.860 & 73.0 & 14.0 & 59.0 \\
\hline & 1.00 & $\mathrm{Eu}^{3+}$ & 0.006 & 0.24 & 99.4 & 76.0 & 23.4 \\
\hline & 1.00 & $\mathrm{Sr}^{2+}$ & 0.08 & 0.96 & 92.0 & 4.0 & 88.0 \\
\hline \multirow{3}{*}{$\underline{\mathbf{E}}$} & 1.10 & $\mathrm{Cu}^{2+}$ & 0.17 & 0.95 & 84.5 & 13.6 & 70.9 \\
\hline & 1.00 & $\mathrm{Eu}^{3+}$ & 0.13 & 0.24 & 87.0 & 76.0 & 11.0 \\
\hline & 1.00 & $\mathrm{Sr}^{2+}$ & 0.26 & 0.96 & 74.0 & 4.0 & 70.0 \\
\hline
\end{tabular}

Synthesis of sorbent based on grafted D onto Merrifield resin

Vanillin is alkylated with chloroethanol in the presence of aqueous $\mathrm{NaOH}$ to yield 4-(2-hydroxyethoxy)-3-methoxybenzaldehyde (79\%). Then the latter is grafted onto the Merrifield resin in the presence of $\mathrm{NaOH}$ in toluene. Afterwards the resulting resin is treated with methanolic ammonia with adding salicylaldehyde at reflux for $10 \mathrm{~min}$. Finally, the product is filtered out from the hot reaction mixture and washed with methanol (Scheme 2).

\subsection{Sorption studies}

$0.1 \mathrm{~g}$ of the properly prepared sorbent was flooded with $25 \mathrm{ml}$ of the solution containing copper, strontium and europium ions in a concentration of $1 \mathrm{mg} \cdot \mathrm{L}^{-1}$ of each. Sorption of the metal ions was carried out at room temperature for $30 \mathrm{~min}$ under magnetic stirring. The solution was filtered through a filter paper. A stock solution of the metal ions was used as a reference one at atomic emission spectroscopy measurements.

\section{Results and discussion}

As shown earlier, the conditions for the formation of complexes with monomer as a modifier and on modified silica gels vary insignificantly. That makes it possible to transfer the optimal conditions for complexation in solutions to the sorption mode [20]. Therefore, in order to elucidate the compounds with most effective ability to surface functionalisation of solid adsorbents, 22 specially synthesized compounds of class of partially hydrogenated azoloazines were screened to their ability to form complexes with target metal ions. The most promising PHHC were selected based on the optical data of their complexes with the studied metal ions (Table 1).

Sorption of ions depends on their charge, size and ability to hydration. The degree of ions sorption increases with the rise of their valences and radiuses [21]. Table 2 shows that the recovery rate of the metal ions on silica gel impregnated by $\underline{\mathbf{C}}$ and $\underline{\mathbf{D}}$ grows in a series of $\mathrm{Cu}^{2+}<\mathrm{Sr}^{2+}<\mathrm{Eu}^{3+}$, which corresponds to the lyotropic series for di- and trivalent cations. At sorption of metal ions on pure silica gel, the degree of re- 


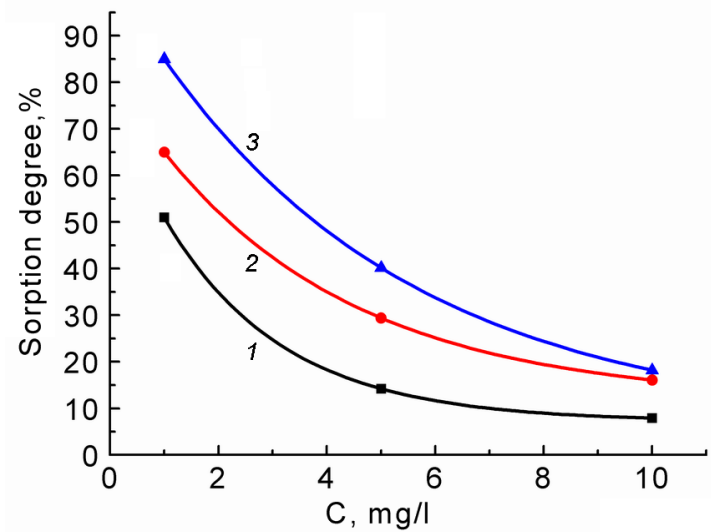

Fig. 1. Concentration dependence of the degree of sorption of $\mathrm{Cu}^{2+}(1), \mathrm{Sr}^{2+}(2), \mathrm{Eu}^{3+}$ (3) by Merrifild resin modified by the compound $\underline{\mathbf{D}}$ ( $C$ is metal ion concentration).

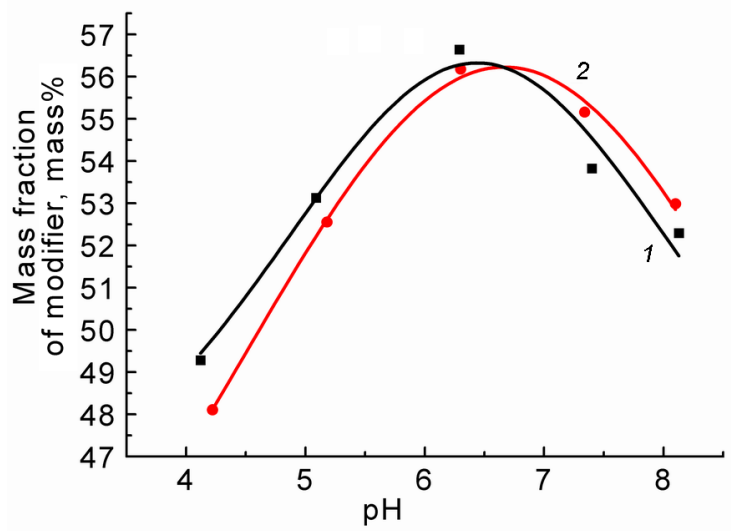

Fig. 3. Content of the $\underline{\mathbf{B}}$ (1) and $\underline{\mathbf{D}}$ (2) modifiers on silica gel surface after extraction of metal ions from aqueous solutions with different $\mathrm{pH}$ values.

covery grows in the series $\mathrm{Sr}^{2+}<\mathrm{Cu}^{2+}<\mathrm{Eu}^{3+}$, since at $\mathrm{pH} \sim 7$ hydroxide complexes of $\mathrm{Cu}^{2+}$ with a radius exceeding the radius of $\mathrm{Sr}^{2+}$ are formed in the aqueous solution. It should be noted that for sorbents based on silica gel modified by $\underline{\mathbf{A}}, \underline{\mathbf{B}}$ or $\underline{\mathbf{E}}$, the degree of recovery falls in the region of ions of equal valence $\left(\mathrm{Sr}^{2+}<\mathrm{Cu}^{2+}\right)$ is observed, which is probably due to the nature of the modifier acting as a complexing agent. In general, we can conclude from Table 2 that modification of silica gel significantly increases its sorption properties. So europium, copper and strontium degree of sorption increases by 7.7 and $23.4 \%$ (using $\underline{\mathbf{A}}$ and $\underline{\mathbf{D}}$ as a modifiers), 11.7 and 70.9 (using modifiers $\underline{\mathbf{B}}$ and $\underline{\mathbf{E}}$ ) and by $8.6-88.0 \%$ (using modifier $\underline{\mathbf{C}}$ and $\underline{\mathbf{D}})$, respectively. From Table 2 it is clear that the sorbent based on the silica gel modified by $\underline{\mathbf{D}}$ has a high degree of sorption of all three target metal ions, while the sorbent based on the silica gel modified by $\underline{\mathbf{B}}$ has a high selectivity for europium. Moreover, such high values of the degree of $\mathrm{Eu}^{3+}$ and $\mathrm{Sr}^{2+}$ sorption by

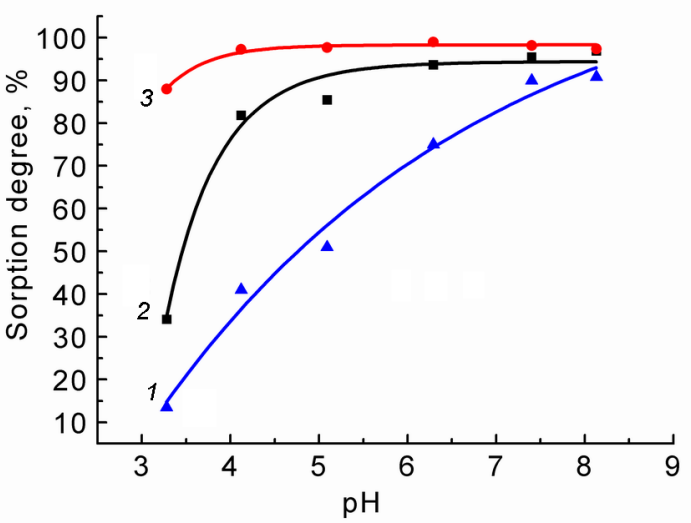

Fig. 2. Dependence of the degree of sorption of metal ions by the sorbent modified by the compound $\underline{\mathbf{B}}$ on $\mathrm{pH}$ of the solution $\left(1-\mathrm{Sr}^{2+}, 2-\mathrm{Cu}^{2+}\right.$, $\left.3-\mathrm{Eu}^{3+}\right)$.

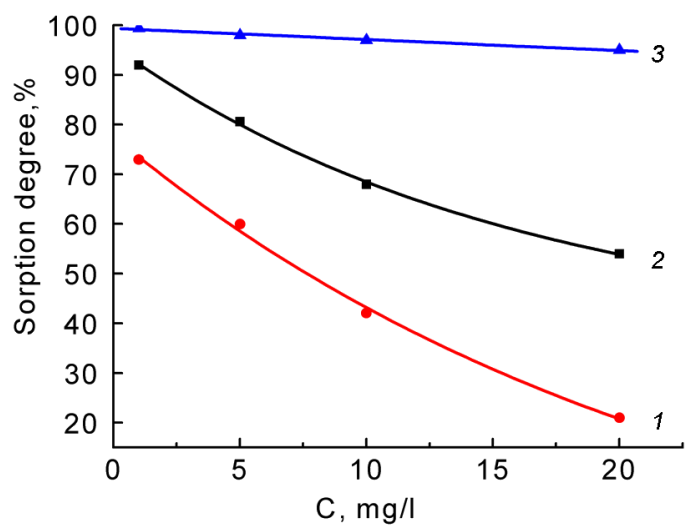

Fig. 4. Concentration dependence of the degree of sorption of $\mathrm{Cu}^{2+}(1), \mathrm{Sr}^{2+}(2), \mathrm{Eu}^{3+}(3)$ by silica gel, modified by the compound $\underline{\mathbf{D}}$ from the water solution at $\mathrm{pH}=7$ ( $\mathrm{C}$ is metal ion concentration).

silica gel modified with $\underline{\mathbf{D}}$ (99.4\% and 92\% respectively) make it possible to use this sorbent for concentration the aforementioned metal ions with initial concentrations near $1 \mathrm{mg} \cdot \mathrm{L}^{-1}$ for quantitative analysis [22].

To quantify the complexing properties of the modifier $\underline{\mathbf{D}}$ it was grafted onto Merrifield resin. Since the latter is an inert carrier which does not contribute to the sorption process, the sorption degree of Merrifild resin modified by the compound $\underline{\mathbf{D}}$ is determined exclusively by the complexing properties of the modifier. As seen from Fig. 1, the compound $\underline{\mathbf{D}}$ has high complexing properties, since the degree of sorption of $\mathrm{Eu}^{3+}$ at its initial concentration of $1 \mathrm{mg} \cdot \mathrm{L}^{-1}$ is $85 \%$. At the same time, the degree of sorption of all metal ions decreases sharply with the rise of their concentration.

The dependence of the sorbtion degree of $\mathrm{Cu}^{2+}(1), \mathrm{Sr}^{2+}(2), \mathrm{Eu}^{3+}(3)$ by the sorbent modified by the compound $\underline{\mathbf{B}}$ from $\mathrm{pH}$ was investigated in the $\mathrm{pH}$ range of $3.5-8.5$ (Fig. 2). In accor- 


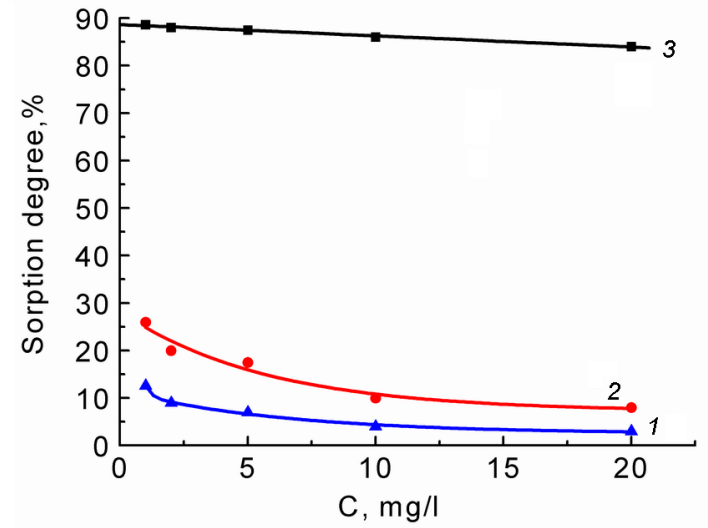

Fig. 5. Concentration dependence of the degree of sorption of Sr (1), Cu (2), Eu (3) by silica gel, modified by the compound $\mathbf{B}$ from the water solution at $\mathrm{pH}=7$ ( $C$ is metal ion concentration).

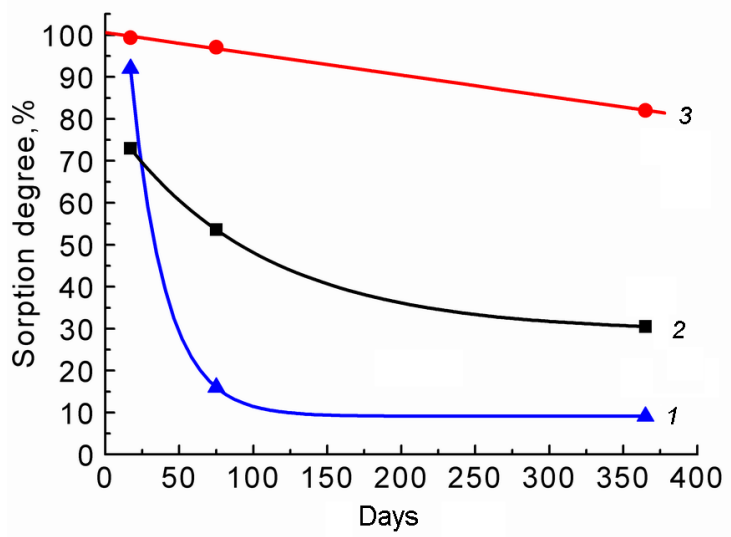

Fig. 7. Dependence of the degree of sorption of metal ions on a sorbent based on silica gel modified by $\underline{\mathbf{D}}$ on the modifier storage time $\left(1-\mathrm{Sr}^{2+}\right.$, $\left.2-\mathrm{Cu}^{2+}, 3-\mathrm{Eu}^{3+}\right)$.

dance with the literature data the shape of the obtained curves is due to the nature of the cation [23]. For the non-hydrolysing $\mathrm{Sr}^{2+}$ the sorption rises with the increase of $\mathrm{pH}$ is observed. For hydrolyzed ions such as $\mathrm{Cu}^{2+}$ and $\mathrm{Eu}^{3+}$, an increase in the degree of sorption with increasing $\mathrm{pH}$ is also observed. However, after reaching the $\mathrm{pH}$ value coinciding with the isoelectric point of the colloid, the value of the sorption degree does not change further.

As seen from Fig. 2, the completeness of the sorption of $\mathrm{Cu}^{2+}$ and $\mathrm{Eu}^{3+}$ on the sorbent modified by compound $\underline{\mathbf{B}}$ is achieved already at $\mathrm{pH} \geq 5$, which makes it suitable for purification from these metal ions of natural waters which $\mathrm{pH}$ value usually varies within $6.5-8.5$. In the presence of $\mathrm{Sr}^{2+}$, the completeness of sorption for the sum of metal ions increases when the $\mathrm{pH}$ raises to a value of $7-8$. One of the disadvantages of non-covalently grafted sorbents is relatively weak, compared to covalent grafted, retention of the reagents on the matrix upon

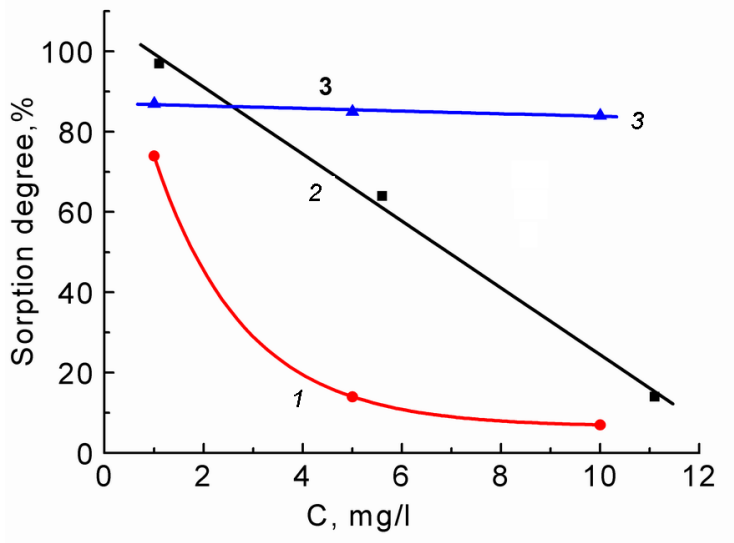

Fig. 6. Concentration dependence of the degree of sorption of Sr (1), Cu (2), Eu (3) by silica gel, modified by the compound $\mathbf{E}$ from the water solution at $\mathrm{pH}=7$ ( $C$ is metal ion concentration).

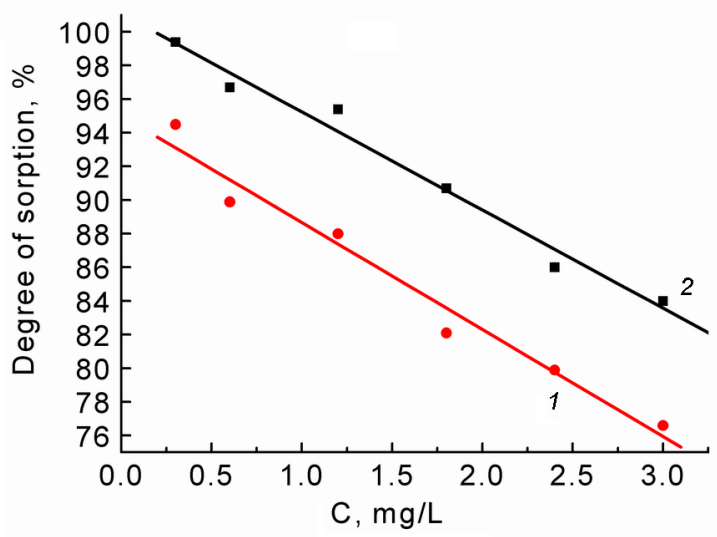

Fig. 8. Dependence of the degree of sorption of $\mathrm{Eu}^{3+}$ with the concentration $1.0 \mathrm{mg} \cdot \mathrm{L}^{-1}$ by silica gel modified by $\underline{\mathbf{B}}$ (1) and $\underline{\mathbf{D}}$ (2) compounds on the total concentration of $\mathrm{Cl}^{-}, \mathrm{HCO}_{3}{ }^{-}$and $\mathrm{SO}_{4}{ }^{2-}$ anions. The concentration of each of the anions in the mixture is the same.

contact with solutions [15]. Therefore there was measured the content of the modifiers $\underline{\mathbf{B}}(1)$ and $\underline{\text { D }}$ (2) on the surface of silica gel after sorption of metal ions from aqueous solutions with different $\mathrm{pH}$ values (Fig. 3). As seen from Fig. 3, at a solution with $\mathrm{pH}$ near 4 about to $51 \%$ the modifier is eluted from the silica gel surface. In a neutral environment, only $44 \%$ of the modifier is eluted from the silica gel surface. Since the silica gel modified with $\underline{\mathbf{B}}$ and $\underline{\mathbf{D}}$ compounds has high sorption properties (Table 2), it is obvious that the target metal ions can bind not only surface-fixed PHHC molecules, but also those in the solution. Subsequently, the resulting complexes are sorbed on the surface of silica gel, which ensures removal of metal ions from the solution.

The capacity of the sorbents based on silica gel modified by PHHC was evaluated under the opti- 


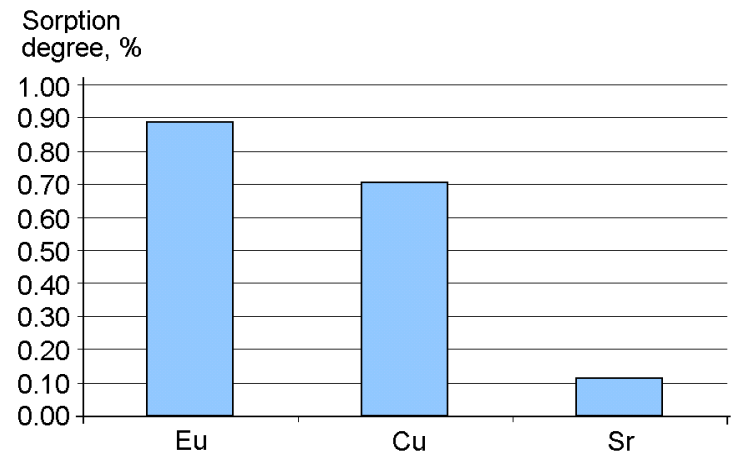

Fig. 9. Degree of extraction of metal ions from natural lightly mineralized water with $\mathrm{pH}=7.0$ silica gel, impregnated by $\underline{\mathbf{B}}$. The sorption time is $20 \mathrm{~min}, \mathrm{t}=20^{\circ} \mathrm{C}$, the sorbent mass is 0.1

mum value $\mathrm{pH}=7$. The concentration dependences of the degree of sorption of $\mathrm{Cu}^{2+}, \mathrm{Sr}^{2+}$ and $\mathrm{Eu}^{3+}$ by the silica gel, modified by the compounds $\underline{\mathbf{B}}$, $\underline{\mathbf{D}}$ and $\underline{\mathbf{E}}$ from the water solution have a similar form (Fig.4 - 6). If the degree of $\mathrm{Eu}^{3+}$ sorption decreases insignificantly with the increase in its concentration from 1 to $20 \mathrm{mg} \cdot \mathrm{L}^{-1}$, a sharp drop in the degree of $\mathrm{Cu}^{2+}$ and $\mathrm{Sr}^{2+}$ sorption is observed in this same concentration range. Obviously, when europium is sorbed on hybrid sorbents based on silica gel, it is the matrix that defines the nature of the sorption process (Table 2). On the contrary, copper and strontium ions are sorbed on hybrid sorbents mainly by the complex-forming process with the modifiers (Fig. 1). The proposed mechanism of sorption is also confirmed by the results of studying the aging process of the modifier, accompanied with oxidation of the phenolic fragments of the modifier with air oxygen. As seen from Fig. 7, the degree of $\mathrm{Eu}^{3+}$ sorption falls only by $15 \%$ when using a sorbent stored for 360 days, while the degree of sorption of $\mathrm{Cu}^{2+}$ and $\mathrm{Sr}^{2+}$ decreases by 30 and $80 \%$, respectively. This phenomenon can be useful when it is necessary to selectively extract $\mathrm{Eu}^{3+}$ from solutions simultaneously containing $\mathrm{Cu}^{2+}$ and $\mathrm{Sr}^{2+}$.

The effect of $100-1000$-fold excess of extraneous anions $\mathrm{Cl}^{-}, \mathrm{HCO}^{3-}$ and $\mathrm{SO}_{4}{ }^{2-}$ on the sorption of $\mathrm{Eu}^{3+}$ ions on silica gel modified by the compound $\underline{\mathbf{B}}$ and $\underline{\mathbf{D}}$ was studied. It is seen from Fig. 8 that the degree of sorption of $\mathrm{Eu}^{3+}$ ions on silica gel modified by PHHC decreases slightly with the rise of the total mineralization in the range of $0.1-2.0 \mathrm{~g} / \mathrm{L}$.

The result of the employing of the silica gel modified by compound $\underline{\mathbf{B}}$ for the separation of the sums of metal ions from natural water confirms that such a sorbent is acceptable for recovering of microquantities of $\mathrm{Eu}^{3+}$ which has been used as chemically identical to ${ }^{241} \mathrm{Am}$ from waters with low mineralization (Fig. 9).

\section{Conclusion}

Created were the sorbents based on silica gel non-covalently modified with partially hydrogenated heterocyclic compounds (PHHC) containing nitrogen as donor atoms. The most promising PHHC were selected based on the optical data of their complexes with metal ions such as $\mathrm{Eu}^{3+}, \mathrm{Cu}^{2+}, \mathrm{Sr}^{2+}$. The sorption properties of the sorbents based on silica gel modified by 5 specimens of PHHC were investigated. The raise of the degree of removal of the metal ions due to modification of the sorbent was evaluated at their initial concentrations near $1 \mathrm{mg} \cdot \mathrm{L}^{-1}$. The $\mathrm{pH}$ dependence of the degree of sorption of metal ions by the sorbent modified by PHHC was investigated on the example of the compound $\underline{\mathbf{B}}$. Also there were found the concentration dependences of the degree of sorption of metal ions by silica gel, modified by 3 samples of PHHC from the water solution at $\mathrm{pH}=7$. The degree of sorption of $\mathrm{Eu}^{3+}$ ions on silica gel modified by PHHC was shown to decrease slightly with the rise of the total mineralization in $0.1-2.0 \mathrm{~g} / \mathrm{L}$ range. Conditions for selective sorption of $\mathrm{Eu}^{3+}$ ions were described. The result of the application of the silica gel modified by the compound $\underline{\mathbf{B}}$ for separation of the sums of metal ions from natural water confirms that such sorbent is acceptable for recovering of microquantities of $\mathrm{Eu}^{3+}$ which has been used as chemically identical to ${ }^{241} \mathrm{Am}$ from waters with low mineralization. Moreover it is shown that silica gel modified by D is possible to use as a sorbent to concentrate the $\mathrm{Eu}^{3+}$ and $\mathrm{Sr}^{2+}$ metal ions with initial concentrations near $1 \mathrm{mg} \cdot \mathrm{L}^{-1}$ for the quantitative analysis. A possible mechanism of metal ion sorption on the developed sorbents was proposed.

\section{References}

1. N.M. Barysheva, E.V. Polyakov, G.P. Shveikin, , et al, WasteECo, 6th International Conference, Kharkiv, Ukraine, 2009 [in Russian]. http:// waste.ua/eco/2009/industrial-waste/sorbent/ .

2. A. Tripathi, M.R. Ranjan, J Bioremediat Biodegrad, 6, 315 (2015).

3. A. Oszczak, L. Fuks, NUKLEONIKA, 60, 927 (2015)

4. B.V. Tangahu, S.R.S. Abdullah, H. Basri et al, International Journal of Chemical Engineering, 2011, Article ID 939161, 2011.

5. M.V. Dvadnenko, N.M. Privalova, I.Yu. Kudaeva et al, Sovremennye naukoemkie tekhnologii, №10, 214, 2010 [in Russian].

6. P. Tzvetkova, R. Nickolov, J. Univ. Chem. Technol. Metallurgy, 47, 498 (2012).

7. A.A. Christy, IACSIT International Journal of Engineering and Technology, 4, 484, 2012. 
8. N.L.D. Filho, L. Caetano, D.R. do Carmo, A.H. Rosa, J. Braz. Chem. Soc., 17, 473, 2006.

9. D. Kara, A. Fisher, Separation \& Purification Reviews, 41, 267, 2012.

10. Himiya geterociklicheskih soedinenij. Sovremennye aspekty, ICSPF, Moscow, 1, 2014 [in Russian].

11. Tsumaki, Bull Chem Soc Jpn, 13, 579, 582, 1938.

12. J.C. Pariaud, D.Labeille, Bull. Soc. Chim. Fr., 429, 1956.

13. O. A. Zaporozhets, O. M. Gaver, V. V. Sukhan, Rus. Chem. Rev. 66, 637, 1997.

14. S.D. Tataeva, U.G.Byurnieva, R.Z. Zeinalov et al, J. Anal. Chem., 66, 363, 2011.

15. R.Z. Zejnalov, S.D. Tataeva, N.I. Ataeva, Analitika i kontrol', 17, 89, 2013 [in Russian].

16. E.Gladkov, S. Sirko, B. Khanetskii et al, Chem. Pap., 61(2) 146, 2007.
17. E. A. Muravyova, V. V. Tkachenko, S. M. Desenko et al, ARKIVOC, 3, 338, 2013.

18. O'Callaghan, N.Conor, McMurry et al, J.Chem. Reasearch (Miniprint), 6, 1549,1988.

19. Desenko, S. M.; Orlov, V. D.; Getmanskii, N. V. et al, Chemistry of Heterocyclic Compounds, 29 (10), 1353, 1993.

20. V.M. Ivanov, S.A. Morozko, Yu. A. Zolotov, Zhurn. Analit. Himii, 48, 1389, 1993 [in Russian].

21. D.A.Fridrigsberg. Kurs kolloidnoj himii (Ucheb. dlja vuzov), Himija, Leningrad, 1984 [in Russian].

22. Atsushi Mizuike, Enrichment Techniques for Inorganic Trace Analysis, Springer-Verlag Berlin Heidelberg, 1983.

23. Korenman I.M., Analiticheskaja himija malyh koncentracij, Himija, Moscow, 1967 [in Russian]. 